\title{
Yield and physical characterization of Passiflora cincinnata in the Brazilian Savanna ${ }^{1}$
}

\author{
Ana Claudia Alves D'Abadia ${ }^{2}$, Ana Maria Costa ${ }^{3}$, \\ Fábio Gelape Faleiro ${ }^{3}$, Juaci Vitória Malaquias ${ }^{3}$, Francisco Pinheiro de Araújo ${ }^{4}$
}

\section{ABSTRACT}

For the Caatinga passion fruit (Passiflora cincinnata Mast.), there are no indications of varieties specific for the Brazilian Savanna conditions, as well as conduction techniques that make it possible to express a greater yield potential. This study aimed to evaluate the yield and quality of CPEF2220 and CBAF2334 populations in espalier and trellis conduction systems. A completely randomized design was used, in a 2 × 2 factorial arrangement, with three replications of four plants per plot. The fruit yield and physical characteristics were evaluated throughout the production cycle. The average yield was $8.0 \mathrm{~kg}$ plant $^{-1}\left(3.5-14.9 \mathrm{~kg}\right.$ plant $\left.{ }^{-1}\right)$ and the average number of fruits per plant was 139.1 (55.8-283.5), with average pulp yield of $29 \%$. There was a tendency to increase the number and yield of fruits for the CPEF2220 population conducted in the espalier system. The plant survival rate was $41 \%$ (CPEF2220) and $87.5 \%$ (CBAF2334), with a higher adaptation to the Brazilian Savanna conditions, while the CPEF2220 population presented a higher yield potential. Reductions in mass, longitudinal and equatorial diameter and fruit shape were observed throughout the harvest, with some exceptions for the espalier system, which showed more elongated fruits. The trellis system showed a greater yield potential for the parent populations of the passion fruit BRS Sertão Forte, for the study conditions.

KEYWORDS: Caatinga passion fruit, tropical fruit, espalier and trellis conduction systems.

\section{INTRODUCTION}

The Passiflora cincinnata Mast. species produces fruits of green color and is popularly known as Caatinga passion fruit, or bush passion fruit. It is native from the biomes Caatinga, Cerrado (Brazilian Savanna) and transition areas between the Brazilian

\section{RESUMO}

\section{Produtividade e caracterização física de Passiflora cincinnata no Cerrado}

Para o maracujazeiro-da-caatinga (Passiflora cincinnata Mast.), não há indicações de variedades específicas para condições de Cerrado e técnicas de condução que possibilitem a expressão de maior potencial produtivo. Objetivou-se avaliar a produtividade e qualidade de populações CPEF2220 e CBAF2334 em sistema de condução espaldeira e latada. Utilizou-se delineamento inteiramente casualizado, em arranjo fatorial $2 \times 2$, com três repetições de quatro plantas por parcela. Foram avaliadas a produtividade e características físicas dos frutos ao longo do ciclo produtivo. A produtividade média foi de $8,0 \mathrm{~kg}_{\text {planta }}{ }^{-1}\left(3,5-14,9 \mathrm{~kg}_{\text {planta }}^{-1}\right) \mathrm{e}$ o número médio de frutos por planta de $139,1(55,8-283,5)$, com rendimento médio de polpa de $29 \%$. Houve tendência de aumento no número e produtividade de frutos na população CPEF2220 conduzida em espaldeira. A taxa de sobrevivência das plantas foi de $41 \%$ (CPEF2220) e 87,5\% (CBAF2334), com maior adaptação às condições de Cerrado, enquanto a população CPEF2220 apresentou maior potencial produtivo. Houve reduções na massa, diâmetro longitudinal e equatorial e formato do fruto ao longo da safra, com algumas exceções no sistema espaldeira, o qual evidenciou frutos mais alongados. O sistema latada apresentou maior potencial produtivo de populações dos genitores do maracujazeiro BRS Sertão Forte, para as condições em estudo.

PALAVRAS-CHAVE: Maracujá-da-caatinga, fruto tropical, sistemas de condução espaldeira e latada.

Savanna and Caatinga (Oliveira \& Ruggiero 2005, Kiill et al. 2010).

There are commercial crops of this species, but most of the fruits available on the market come from extractivism (Kiill et al. 2010), a system in which a low yield may result from a high genetic variability within populations, where plants with higher

\footnotetext{
${ }^{1}$ Received: Sep. 23, 2020. Accepted: Jan. 15, 2021. Published: Feb. 11, 2021. DOI: 10.1590/1983-40632021v5165795.

${ }^{2}$ Universidade de Brasília, Brasília, DF, Brasil.E-mail/ORCID: anadabadia@yahoo.com.br/0000-0001-8401-0377.

${ }^{3}$ Empresa Brasileira de Pesquisa Agropecuária (Embrapa Cerrados), Planaltina, DF, Brasil.

E-mail/ORCID: ana-maria.costa@embrapa.br/0000-0003-4456-7802, fabio.faleiro@embrapa.br/0000-0001-8901-6428, juaci.malaquias@embrapa.br/0000-0001-6720-9624.

${ }^{4}$ Empresa Brasileira de Pesquisa Agropecuária (Embrapa Semiárido), Petrolina, PE, Brasil. E-mail/ORCID: pinheiro.araujo@embrapa.br/0000-0002-5400-4686.
} 
and lower yield potential are observed (Viana \& Gonçalves 2005). Thus, in order to reach a greater yield efficiency, the availability of improved cultivars adapted to commercial cultivation is necessary (Viana \& Gonçalves 2005).

The BRS Sertão Forte (BRS SF) variety is available on the market, resulting from the crossing of two populations (CBAF2334 and CPEF2220) of plants originated and selected in the Brazilian semi-arid region. Under conditions of the Pernambuco state and in the Brazilian Savanna of the midwest plateau (highland), the variety may produce 18-30 t ha ${ }^{-1}$ year-1, depending on the crop management conditions (Embrapa 2016).

Due to the climatic differences between the semi-arid region (Moura et al. 2007) and the Brazilian Savanna (Coutinho 2018), it is necessary to understand the productive performance of parents under specific conditions of the Brazilian Savanna for different conduction systems (espalier and trellis), what may contribute to understand the variety and establish strategies for cultivation recommendations.

The conduction of plants in a trellis system results in a higher fruit yield for the $P$. edulis species, if compared to the espalier one, whereas the $P$. setacea species yields about $13,754 \mathrm{~kg} \mathrm{ha}^{-1}$ in the trellis and 10,492 $\mathrm{kg} \mathrm{ha}^{-1}$ in the espalier systems (Komuro 2008, Costa et al. 2014).

Although the trellis conduction system yields $30-40 \%$ more, when compared to the wire espalier conduction system, it must be considered that the cost for implementing it is higher (Rigden 2011), since more support brackets are required to accommodate the main wire, as well as more time and labor. For $P$. cincinnata, there is lack of information regarding the conduction system, what is important for decisionmaking, due to the higher cost of implementation and maintenance when carried out in trellises, if compared to espaliers (Carvalho et al. 2015).

Thus, this study aimed to evaluate the yield and quality of CBAF2334 and CPEF2220 populations, which have the parental genotypes of the P. cincinnata cv. BRS SF, under cultivation conditions in the Brazilian Savanna, using the espalier and trellis conduction systems.

\section{MATERIAL AND METHODS}

Parental populations of the Passiflora cincinnata cv. BRS SF, CBAF2334 and CPEF2220, which are part of the Embrapa Semiárido germplasm bank, were evaluated. The populations were cultivated between April 2015 and July 2016, at the Embrapa Cerrados, in Planaltina, DF, Brazil (15³6'13.02"S, $47^{\circ} 43^{\prime} 17.34^{\prime \prime} \mathrm{W}$ and average altitude of $1,050 \mathrm{~m}$ ).

Pits with dimensions of $60 \mathrm{~cm}$ in diameter and $60 \mathrm{~cm}$ in depth were made with the aid of a motorized drill bit. Planting fertilization was carried out based on the soil analysis, using as a reference the fertilization for sour passion fruit: dolomitic limestone to raise the $\mathrm{V}$ to $50 \%$ (Brasil \& Nascimento 2010); $250 \mathrm{~g} \mathrm{pit}^{-1}$ of $\mathrm{P}_{2} \mathrm{O}_{5}$ (source: simple superphosphate); $100 \mathrm{~g} \mathrm{pit}^{-1}$ of $\mathrm{N}$ (source: ammonium sulphate); $100 \mathrm{~g} \mathrm{pit}^{-1}$ of $\mathrm{K}_{2} \mathrm{O}$ (source: potassium chloride); $100 \mathrm{~g} \mathrm{pit}^{-1}$ of FTE BR12; and $10 \mathrm{~L} \mathrm{pit}^{-1}$ of organic matter (source: chicken litter). The first cover fertilization was carried out at 60 days after planting, followed by others at 45-day intervals, using $100 \mathrm{~g} \mathrm{plant}^{-1}$ (1:2 of potassium chloride and ammonium sulphate).

The crops were implemented in the field as shown in Figures 1A and 1B, with seedlings at the age of three months, on April 09, 2015, in the spacing between plants and between rows $(2.5 \mathrm{~m} \times 2.5 \mathrm{~m}$ for the espalier and $2.5 \mathrm{~m} \times 5.0 \mathrm{~m}$ for the trellis conduction systems). The experimental design for the parents CPEF2220 and CBAF2334 was completely randomized, with three replications of four plants for each conduction system (trellis and espalier) (Figure 1A).

For the study of fruit yield and physical characteristics carried out between November 2015 and July 2016, each population and its respective conduction system with three replications were considered, with 10 fruits per plot and all fruits of the plot being analyzed in the harvest of July 2016 .

For the physical evaluations of fruits carried out between May and June 2016, a factorial arrangement $(2 \times 2)$ was considered, being two populations (CBAF2334 and CPEF2220) and two conduction systems (espalier and trellis), with three replications each and eight fruits analyzed per plot.

The climatic conditions of the cultivation period (April 2015 to July 2016) were expressed by an average temperature of $22.1^{\circ} \mathrm{C}$, average relative humidity of $64.2 \%$ and precipitation of $1,090 \mathrm{~mm}$. The fruits of the plants from each plot were collected weekly from November 2015, the beginning of the first harvest. The collection took place after the abscission (after detaching from the plant, reaching physiological maturation), until the end of the 

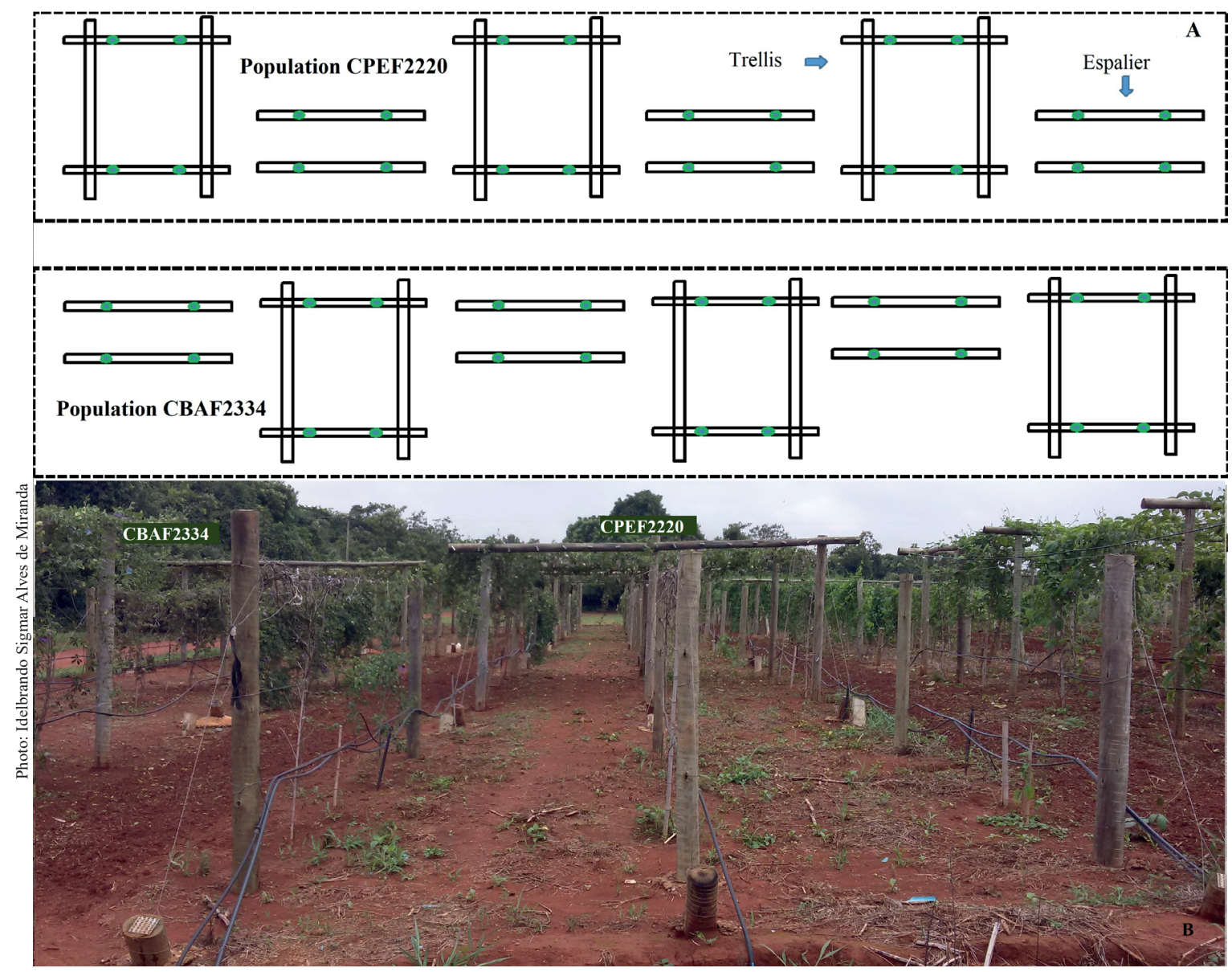

Figure 1. Representation of the experimental cultivation area for Passiflora cincinnata (CPEF2220 and CBAF2334 populations) (circles) conducted in trellis and espalier systems represented by horizontal and vertical bars (A), and photo of the experimental area (B).

material's life cycle (July 2016), with the last harvest comprising the fruits that fell on the soil and those that were trapped in the plant.

The analyzed data were: total number of fruits, obtained by counting the fruits per plant and per plot; longitudinal and equatorial length and diameter of the fruit, determined with a digital caliper (StainlessHardened ${ }^{\mathrm{TM}}$ ); and fruit mass, measured by a centesimal semi-analytical scale (OhausAdventurer ${ }^{\mathrm{TM}}$ ). The values for total mass and number of fruits were determined per plant. The mass and respective longitudinal (length) and equatorial (width) diameters were determined by analyzing 10 fruits from each plot, according to availability and collected weekly.

During the months of May and June 2016, of the ten fruits per plot, eight were evaluated for peel/skin thickness with a digital caliper (StainlessHardened $^{\mathrm{TM}}$ ); peel and pulp mass (with and without seeds) obtained on a semi-analytical centesimal scale (OhausAdventurer ${ }^{\mathrm{TM}}$ ); pulp volume with and without seeds determined in a $100 \mathrm{~mL}$ graduated cylinder; and fruit shape obtained by the ratio between longitudinal (length) and equatorial diameter.

The seeds were detached from the pulp using a food blender with a blunt blade, and soon after they were separated from the pulp in a sieve. The seed fresh weight was determined by the difference in the pulp mass with and without seeds. The pulp yield was calculated in percentage values from the mass/mass ratio of the pulp without and with seeds per fruit, and the mass/mass ratio and volume/volume of the pulp without seeds per pulp with seeds.

Regression analyses were performed in each population and its respective conduction system to evaluate the monthly yield of fruits harvested on the ground between November 2015 and July 2016. For 
the physical characteristics of the fruits collected between May and June 2016, a 2 x 2 factorial scheme (populations $\mathrm{x}$ conduction systems) was used in a completely randomized design. The significance of the treatments was evaluated by variance analysis (Anova), the assumptions of normality for the residues were verified by the Shapiro-Wilk test (Miot 2017), and the homogeneity of variance by means of the Levene test (Levene 1960). For the comparison of means, the Tukey test was used, at $5 \%$ of probability. All analyses were performed by the R statistical software, version 3.5.0 (R Core Team 2018).

\section{RESULTS AND DISCUSSION}

The total fruit yield of $P$. cincinnata (CPEF2220 and CBAF2334) conducted in the espalier and trellis systems ranged from 3.5 to $14.9 \mathrm{~kg} \mathrm{plant}^{-1}$, with mean value of $8.0 \mathrm{~kg} \mathrm{plant}^{-1}$. The linear regression analysis showed the existence of a different behavior in yield for the two populations in the two conduction systems (Figures 2A and 2B). There was a trend of linear increase in yield only for the CPEF2220 population conducted in the espalier system (Figure 2A).

A higher yield for the CPEF2220 population was observed in the trellis system (Figure 2A), which represented an average yield potential $(125.7 \%)$ higher than that for the espalier system. A similar behavior was observed in relation to the average number of fruits per plant, whose values varied from 55.8 to 283.5 fruits plant $^{-1}$, with an average of 139.1 fruits plant $^{-1}$. The CPEF2220 population showed a fruit yield $153.7 \%$ higher than the CBAF2334 one.

Similarly to yield, a tendency to increase the number of fruits per plant (Figure 2C) was observed only in the espalier system of the CPEF2220 population; while, in the trellis system of this population and in both systems for the CBAF2334 population, the same fact did not occur, indicating
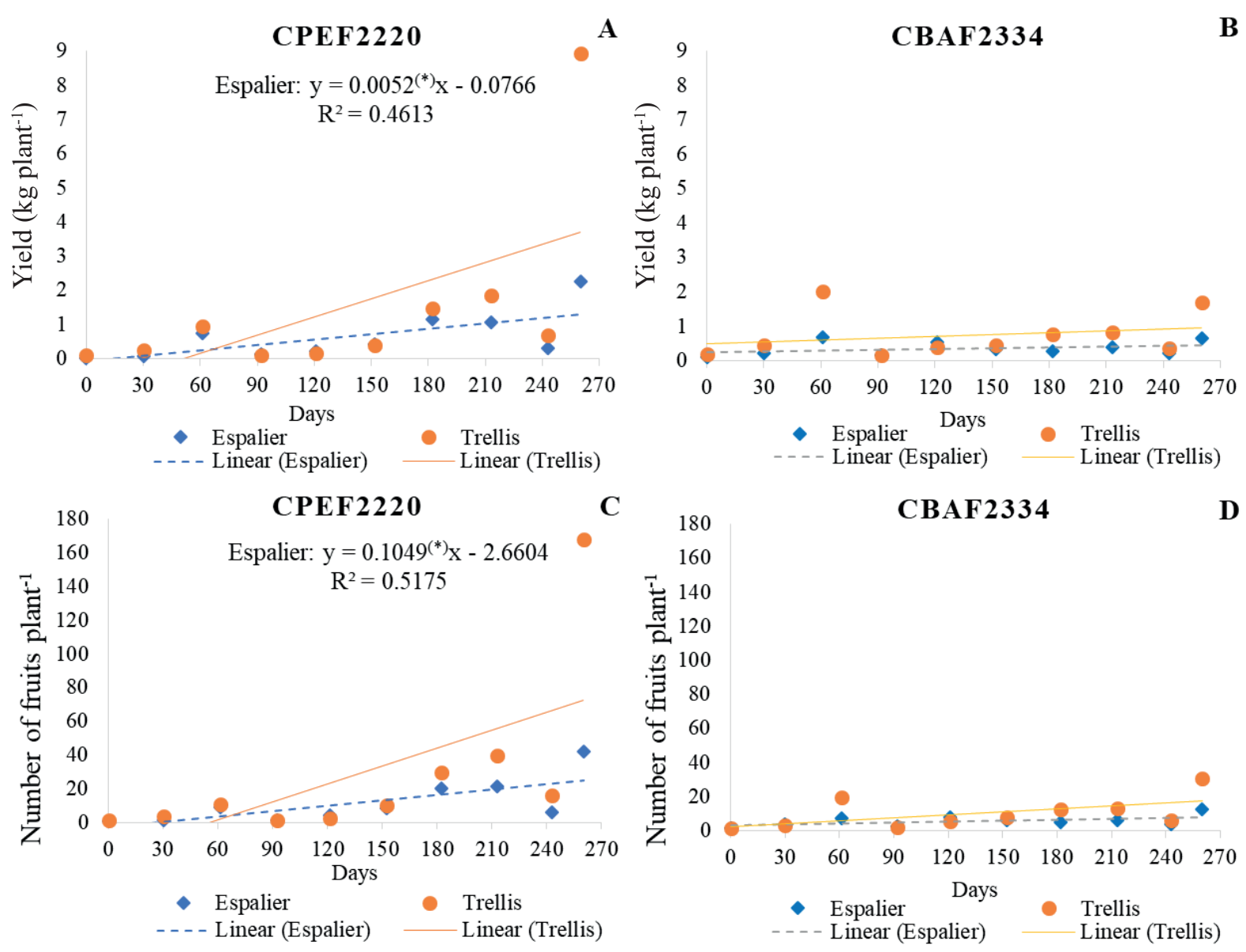

Figure 2. Fruit yield per plant (A and B) and total number of fruits per plant (C and D) for the CPEF2220 (A and C) and CBAF2334 (B and D) populations of Passiflora cincinnata conducted in espalier and trellis systems. * Significant at $5 \%$ by the F test. 
a random number of fruits per plant that suffer abscission along the production period and harvest.

The obtained result was close to the average yield of 32 accessions of $P$. cincinnata cultivated in Petrolina (Pernambuco state, Brazil), in the espalier conduction system (Araújo et al. 2008), which was $15.88 \mathrm{~kg}$ plant $^{-1}$.

Costa et al. (2014) also observed a higher yield for P. setacea (BRS PC) in the trellis conduction system, in relation to the espalier one, possibly due to the better distribution of the plant branches in the trellis, in relation to the espalier, and a consequent greater exposure to the sun and pollinators (Guimarães et al. 2013, Costa et al. 2014).

The CPEF2220 and CBAF2334 parents showed a different behavior, concerning the ability to adapt to environmental conditions, regardless of the conduction system. The highest percentage of plant survival was found within the CBAF2334 population $(87.5 \%)$, in relation to the CPEF 2220 one $(41 \%)$.

Individuals who increased the yield by up to three times with the density decrease, as well as others who did not respond to the decrease, were also verified, particularly within the CPEF2220 population.

There was a tendency for a significant decrease in the average fruit mass during the harvest (Figure 3), except for the CPEF2220 population, when carried out in the espalier system, which showed stability for fruit size from the beginning to the end of cultivation.

A trend towards a decrease in fruit mass with an increase in the number of fruits was observed for melon and sour passion fruit (Queiroga et al. 2008,
Nogueira Filho et al. 2011), with the decrease being attributed to competition for plant reserves.

The average fruit mass differed significantly only among the plant populations, with the CBAF2334 population presenting fruits of higher mass (Table 1). There was no significant interaction between conduction factors and plant populations.

The mean fruit longitudinal diameter of the two populations was $53 \mathrm{~mm}$, while the equatorial diameter was $51 \mathrm{~mm}$, varying throughout the fruiting period (Figure 4).

There was a significant trend towards a decrease in the longitudinal and equatorial diameters of the populations conducted in the trellis system (Figure 4). This trend was not observed for the populations when conducted in the espalier system, except for the longitudinal diameter of the CBAF2334 population.

Queiroga et al. (2008) also verified a reduction in the length and width of melon fruits throughout the crop cycle, which was attributed to a higher yield in the number of fruits, a fact that may also have occurred with the $P$. cincinnata fruits (Figures $2 \mathrm{C}$ and 2D).

The relation between the longitudinal and equatorial diameters indicates the shape of the fruit, and, the closer the value to 1 , the more rounded the fruit will be (Jesus et al. 2015). The fruits of the whole trial showed values that varied from 0.95 to 1.14 , indicating a shape close to the rounded one. However, the fruits of the CBAF2334 population proved to be significantly more elongated (Table 1).

Significant differences in the fruit shape were observed between the espalier and trellis conduction

\section{CPEF2220}

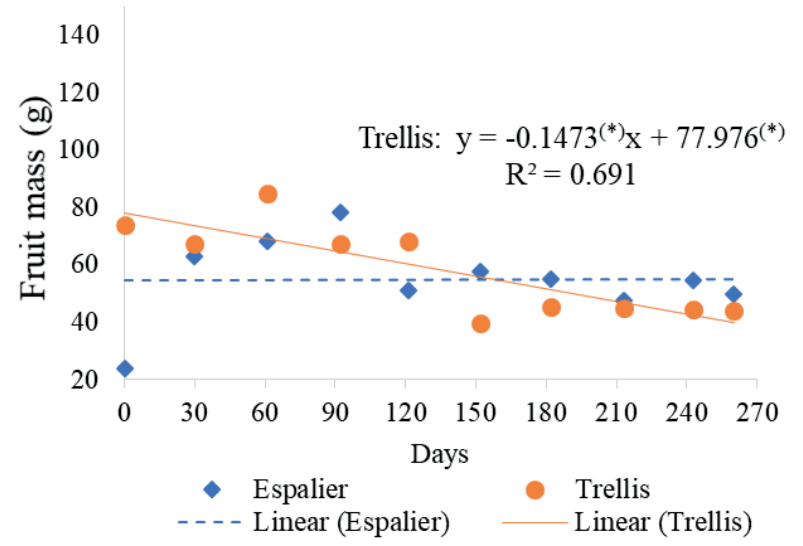

A

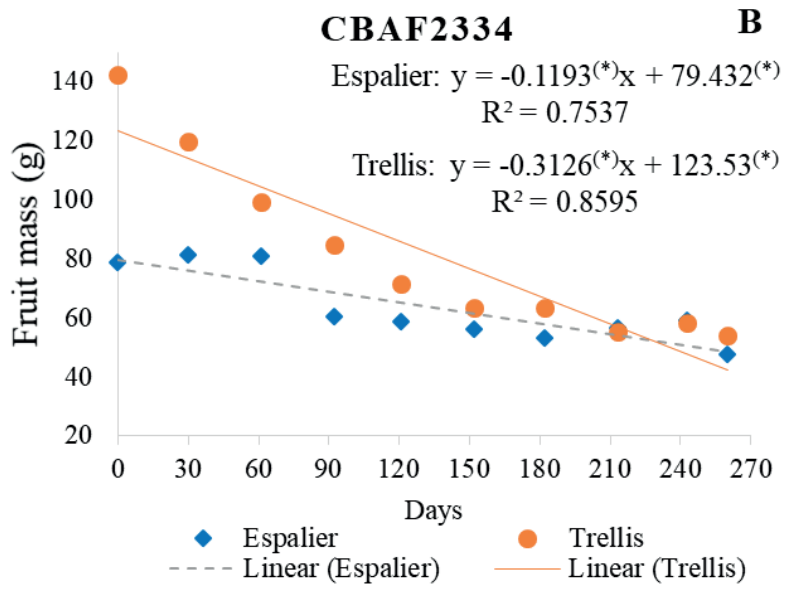

Figure 3. Fruit mass for the CPEF2220 (A) and CBAF2334 (B) populations of Passiflora cincinnata conducted in espalier and trellis systems. * Significant at $5 \%$ by the $\mathrm{F}$ test. 
CPEF 2220

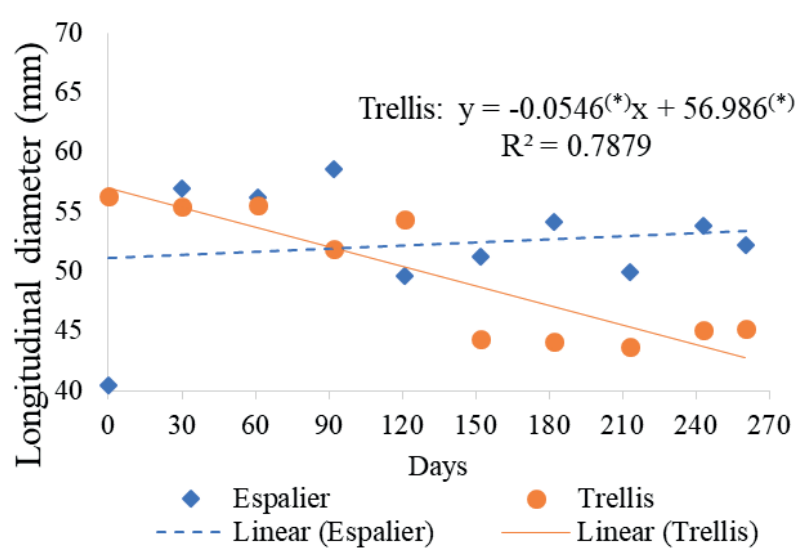

CPEF 2220

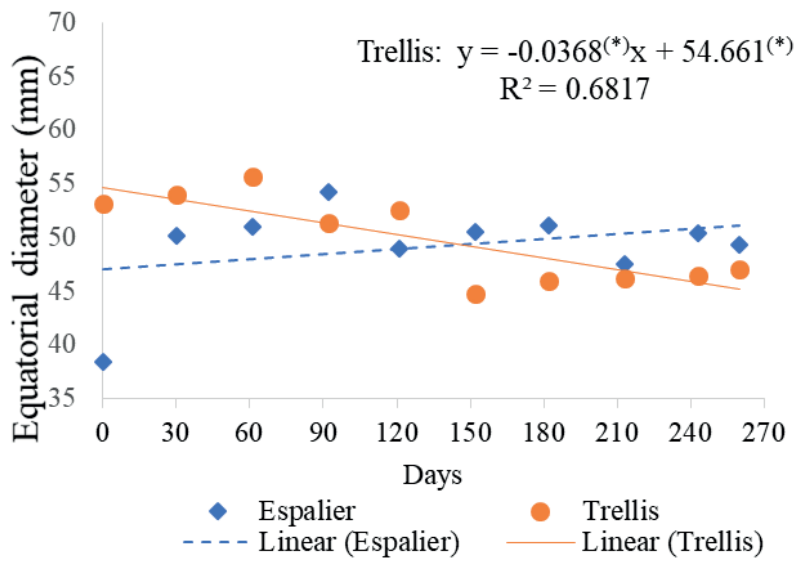

$\mathbf{A}$
CBAF2334

B

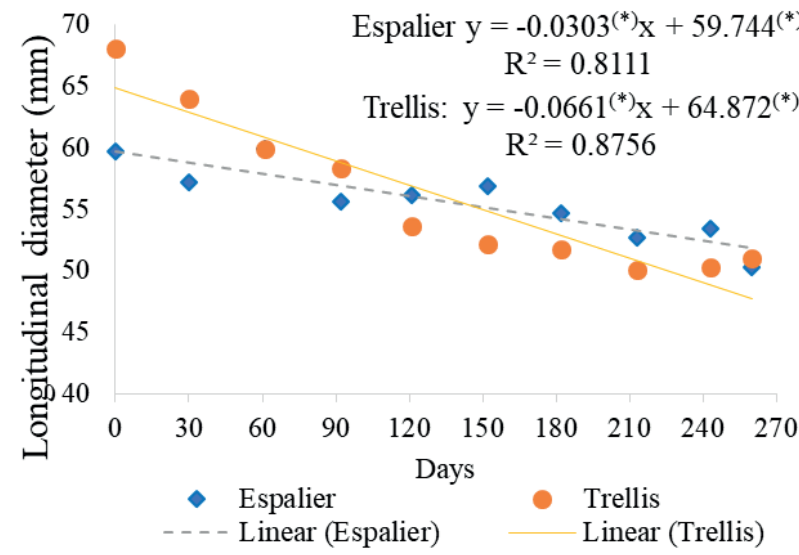

CBAF2334

D

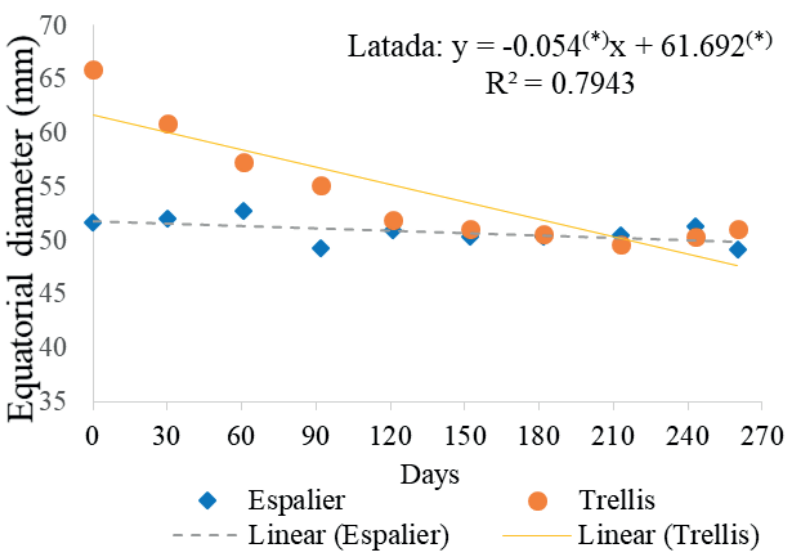

Figure 4. Behavior of the fruit longitudinal (A and B) and equatorial (C and D) diameter of the CPEF2220 (A and C) and CBAF2334 (B and D) populations of Passiflora cincinnata conducted in espalier and trellis systems. * Significant at $5 \%$ by the $\mathrm{F}$ test.

Table 1. Physical characteristics of Passiflora cincinnata fruits from the CPEF2220 and CBAF2334 populations conducted in espalier and trellis systems.

\begin{tabular}{lcccc}
\hline & $F^{1}(\mathrm{~g})$ & $\mathrm{LD}^{2}(\mathrm{~mm})$ & $\mathrm{ED}^{3}(\mathrm{~mm})$ & $\mathrm{LD} / \mathrm{ED}^{4}$ \\
\hline Espalier & $58.23 \mathrm{a}^{5}$ & $53.88 \mathrm{a}$ & $48.38 \mathrm{a}$ & $1.11 \mathrm{a}$ \\
Trellis & $67.79 \mathrm{a}$ & $51.02 \mathrm{a}$ & $52.06 \mathrm{a}$ & $0.97 \mathrm{~b}$ \\
\hline CPEF2220 & $52.50 \mathrm{~b}$ & $49.26 \mathrm{~b}$ & $48.64 \mathrm{a}$ & $1.01 \mathrm{a}$ \\
CBAF2334 & $73.53 \mathrm{a}$ & $55.64 \mathrm{a}$ & $51.80 \mathrm{a}$ & $1.08 \mathrm{a}$ \\
\hline CV $(\%)$ & 21.51 & 7.61 & 7.92 & 6.91 \\
\hline
\end{tabular}

${ }^{1} \mathrm{FM}$ : fruit mass. ${ }^{2} \mathrm{LD}$ : fruit longitudinal diameter. ${ }^{3} \mathrm{ED}$ : fruit equatorial diameter.

${ }^{4} \mathrm{LD} / \mathrm{ED}$ : longitudinal and equatorial diameter ratio. ${ }^{5}$ Means of the same characteristic evaluated in the columns followed by the same letter do not differ by the Tukey test at $5 \%$ of probability.

systems (Table 1), with little evident practical effect. There was a tendency for a significant reduction in the fruit shape, except for the CPEF2220 population conducted in the espalier system, which tended towards a constant shape (Figure 5).
Komuro (2008) evaluating $P$. edulis and Silva et al. (2004) P. alata also observed differences in the fruit size, when using conduits in a vertical espalier and $\mathrm{T}$ espalier (which resembles the trellis because it is positioned horizontally). Variations in the size and shape of $P$. edulis fruits, as a function of the growing environment, were also observed by Scorza et al. (2017). The fruit shape and dimensions are regulated by genes belonging to the MAD-box complex and play an important role during the reproductive development (Cutri \& Dornelas 2012). Scorza et al. (2017) studied two genes of this complex in $P$. edulis and found that PeFUL, FRUITFULL (FULL) homologue, presented a broad pattern of expression in vegetative and reproductive tissues, suggesting that these genes may also be related to the development of $P$. cincinnata fruits.

There was no interaction between the conduction systems and plant population, nor any 
CPEF 2220

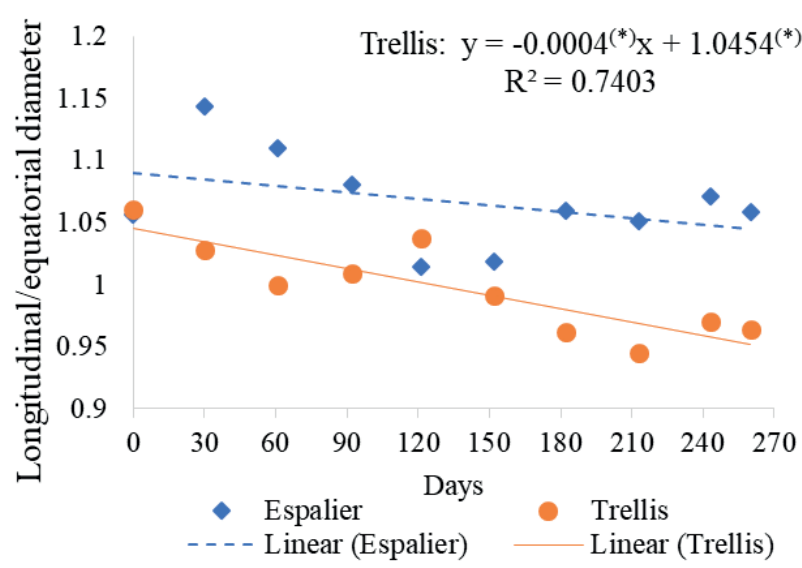

A

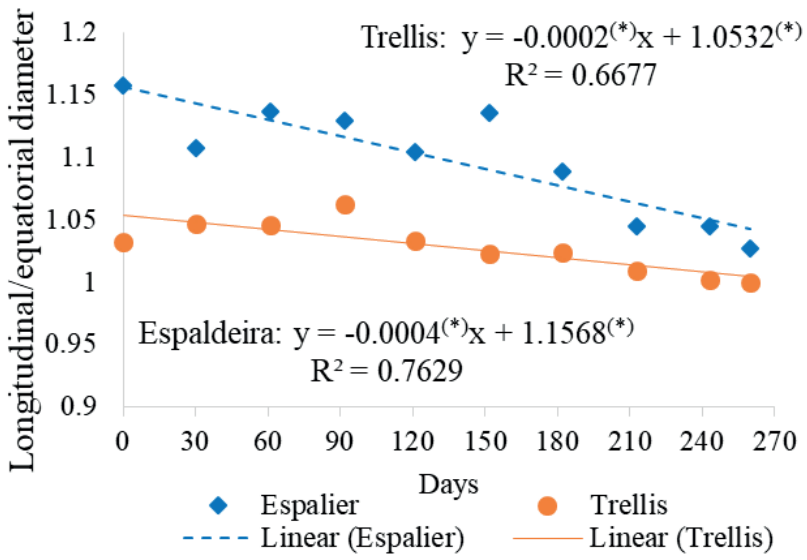

Figure 5. Fruit longitudinal and equatorial diameter ratio of the CPEF2220 (A) and CBAF2334 (B) populations of Passiflora cincinnata conducted in espalier and trellis systems. * Significant at $5 \%$ by the $\mathrm{F}$ test.

significant variation, in relation to the seed mass (Table 2). Significant differences, however, were observed in the peel mass and thickness and in the seedless pulp mass and volume between the CPEF2220 and CBAF2334 plant populations (Table 2). The CPEF2220 population plants showed peel with lower mass and thickness, while fruits of the CBAF2334 population had a greater mass and volume of seedless pulp, indicating that the two genotypes have beneficial characteristics for consumption in retail and industry.

The volume of pulp with seeds for the CBAF2334 population (Table 2) presented a value close to that described by Magalhães (2010) (47.1 mL). The peel thickness of the CPEF2220 population recorded values that can be classified as very thin, and CBAF2334 as thin (Jesus et al. 2015). The significant differences observed in the mass and volume of the seedless pulp (Table 2) between the plant populations were correlated with the greater fruit mass of the CBAF2334 population (Table 1).
There was no interaction or significant differences between the $P$. cincinnata populations and the conduction systems, in relation to pulp yield. The yield of the seedless pulp mass, in relation to the fruit mass, was $26.63-31.37 \%$, with an average value of $29 \%$, while the mass of pulp with seeds, in relation to the fruit mass, was $63.04-66.58 \%$, with an average value of $64.81 \%$. The mass yield of pulp without seeds, in relation to the pulp with seeds, was $40.18-47.29 \%$, with an average value of $43.73 \%$, while the volume yield of pulp without seeds, in relation to the pulp with seeds, was $48.88-49.10 \%$, with an average of $44.99 \%$.

Lessa (2011) observed, for $P$. cincinnata and the BRS SF cultivar, a pulp yield of $31.88 \%$ and $28.70 \%$, respectively, values close to those found in the present study. These values are also close to those found for the P. edulis BRS Sol do Cerrado cultivar (Tupinambá et al. 2012), which presented an average pulp yield with seeds of $31.45 \%$, in relation to the fruit.

Table 2. Physical characteristics of mass and volume of fruit pulp from the CPEF2220 and CBAF2334 populations of Passiflora cincinnata conducted in espalier and trellis systems.

\begin{tabular}{llcccccc}
\hline & $\mathrm{PM}^{1}(\mathrm{~g})$ & $\mathrm{PT}^{2}(\mathrm{~mm})$ & $\mathrm{PM}^{3}(\mathrm{~g})$ & $\mathrm{SM}^{4}(\mathrm{~g})$ & $\mathrm{FSM}^{5}(\mathrm{~g})$ & $\mathrm{PV}^{6}(\mathrm{~mL})$ & $\mathrm{VS}^{7}(\mathrm{~mL})$ \\
\hline Espalier & $20.23 \mathrm{a}^{8}$ & $3.49 \mathrm{a}$ & $37.32 \mathrm{a}$ & $16.84 \mathrm{a}$ & $20.47 \mathrm{a}$ & $36.87 \mathrm{a}$ & $16.70 \mathrm{a}$ \\
Trellis & $20.90 \mathrm{a}$ & $3.07 \mathrm{a}$ & $45.76 \mathrm{a}$ & $23.54 \mathrm{a}$ & $22.23 \mathrm{a}$ & $44.76 \mathrm{a}$ & $23.61 \mathrm{a}$ \\
\hline CPEF2220 & $16.45 \mathrm{~b}$ & $2.96 \mathrm{~b}$ & $34.66 \mathrm{a}$ & $15.14 \mathrm{~b}$ & $19.52 \mathrm{a}$ & $33.84 \mathrm{a}$ & $14.99 \mathrm{~b}$ \\
CBAF2334 & $24.69 \mathrm{a}$ & $3.60 \mathrm{a}$ & $48.42 \mathrm{a}$ & $25.25 \mathrm{a}$ & $23.17 \mathrm{a}$ & $47.79 \mathrm{a}$ & $25.32 \mathrm{a}$ \\
\hline CV $(\%)$ & 21.19 & 14.36 & 26.16 & 36.39 & 17.00 & 26.66 & 37.06 \\
\hline
\end{tabular}

${ }^{1}$ PM: peel mass. ${ }^{2}$ PT: peel thickness. ${ }^{3}$ PM: pulp mass with seeds. ${ }^{4}$ SM: seedless pulp mass. ${ }^{5}$ FSM: fresh seed mass. ${ }^{6}$ PV: pulp volume with seeds. ${ }^{7}$ VS: volume of seedless pulp. ${ }^{8}$ Means of the same characteristic evaluated in the columns followed by the same letter do not differ by Tukey test at $5 \%$ of probability. 


\section{CONCLUSIONS}

1. The trellis conduction system enabled the greatest yield potential of the Passiflora cincinnata populations in the conditions of the Brazilian Savanna, with a greater yield potential for the CPEF2220 population and a higher survival rate for the CBAF2334 population;

2. The $P$. cincinnata fruits showed characteristics of very thin skin/peel and pulp yield compatible with the fruits of $P$. edulis. The trellis conduction system reduced the average value of mass, shape, longitudinal (length) and equatorial (width) diameter of the fruits throughout the fruiting period;

3. The espalier conduction system influenced the fruit shape, which was more elongated, regardless of the evaluated population.

\section{ACKNOWLEDGMENTS}

The study was funded by the Conselho Nacional de Desenvolvimento Científico e Tecnológico (CNPq). The author A. C. A. D'Abadia thanks the Coordenação de Aperfeiçoamento de Pessoal de Nível Superior (Capes) for granting a scholarship and the Universidade de Brasília (UnB) for the opportunity to study. The author also thanks the Embrapa Cerrados and Embrapa Semiárido team, and all the people who contributed to this study, especially the researcher Renato Fernando Amábile and the collaborators Idelbrando Sigamar Alves de Miranda, Daniela Andrade Faria and Márcio Luiz Gonçalves.

\section{REFERENCES}

ARAÚJO, F. P.; SILVA, N.; QUEIROZ, M. A. Divergência genética entre acessos de Passiflora cincinnata Mast. com base em descritores morfoagronômicos. Revista Brasileira de Fruticultura, v. 30, n. 3, p. 723-730, 2008.

BRASIL, E. C.; NASCIMENTO, E. V. S. Influência de calcário e fósforo no desenvolvimento e produção de variedades de maracujazeiro-amarelo. Revista Brasileira de Fruticultura, v. 32, n. 3, p. 892-902, 2010.

CARVALHO, S. L. C.; STENZEL, N. M. C.; AULER, P. A. M. Maracujá-amarelo: recomendações técnicas para cultivo no Paraná. Londrina: Iapar, 2015. (Boletim técnico, 83).

COSTA, A. M.; MORAIS, K. L.; SANTOS, F. E. Influência do tipo de condução na produção e características fisicoquímicas do maracujá silvestre BRS Pérola do Cerrado
(Passiflora setacea). In: CONGRESSO BRASILEIRO DE FRUTICULTURA, 23., 2014, Cuiabá. Anais... Rio de Janeiro: Sociedade Brasileira de Fruticultura, 2014. p. 1-4.

COUTINHO, L. M. Aspectos do Cerrado: clima. 2018. Disponível em: http://eco.ib.usp.br/cerrado/aspectos_ clima.htm. Acesso em: 29 out. 2018.

CUTRI, L.; DORNELAS, M. C. Exploring expressed sequence tags during flower development in Passiflora spp. Comparative and Functional Genomics, v. 2012, p. 1-11, 2012.

EMPRESA BRASILEIRA DE PESQUISA AGROPECUÁRIA (Embrapa). Cultivar de maracujazeiro silvestre (Passiflora cincinnata Mast.) para a Caatinga e para o Cerrado BRS Sertão Forte. Brasília, DF: Embrapa, 2016.

GUIMARÃES, T. C.; DIANESE,A.C.; OLIVEIRA, C. M.; MADALENA, J. O. M.; FALEIRO, F. G.; JUNQUEIRA, N. T. V.; LIMA, H. C.; CAMPOS, G. A. Recomendações técnicas para o cultivo de Passiflora setaceae BRS Pérola do Cerrado. Planaltina, DF: Embrapa, 2013.

JESUS, O.N.; OLIVEIRA, E. J.; SOARES, T.L.; FALEIRO, F. G. Aplicação de descritores morfoagronômicos utilizados em ensaios de DHE de cultivares de maracujazeiro-doce, ornamental, medicinal, incluindo espécies silvestres e hibridos interespecificos (Passiflora spp.): manual prático. Brasília, DF: Embrapa, 2015.

KIILL, L. H. P.; SIQUEIRA, K. M. M.; ARAÚJO, F. P.; TRIGO, S. P. M.; FEITOZA, E. A.; LEMOS, I. B. Biologia reprodutiva de Passiflora cincinnata Mast. (Passifloraceae) na região de Petrolina (Pernambuco, Brazil). Oecologia Australis, v. 14, n. 1, p. 115-127, 2010.

KOMURO, L. K. Efeitos de sistemas de condução sobre o crescimento, produção, qualidade dos frutos e custos de instalação de maracujazeiro amarelo (Passiflora edulis Sims. f. flavicarpa Deg). 2008. Dissertação (Mestrado em Agronomia) - Faculdade de Engenharia, Universidade Estadual Paulista, Ilha Solteira, 2008.

LESSA, A. O. Determinação do teor de compostos fitoquímicos e estudo do potencial para processamento da polpa de frutos de maracujá das espécies silvestres (Passiflora setacea DC, Passiflora cincinnata MAST.). 2011. Dissertação (Mestrado em Engenharia de Alimentos) - Universidade Estadual do Sudoeste da Bahia, Itapetinga, 2011.

LEVENE, H. Robust tests for equality of variances. In: OLKIN, I. (ed.). Contribution to probability and statistics. Stanford: Stanford University Press, 1960. p. 278-292.

MAGAlHÃES, A. C. B. Caracterização de frutos e sementes e germinação de Passiflora edulis Sims f. flavicarpa Degener e Passiflora cincinnata Mast. 
2010. Dissertação (Mestrado em Recursos Genéticos Vegetais) - Universidade Estadual de Feira de Santana, Feira de Santana, 2010.

MIOT, H. A. Avaliação da normalidade dos dados em estudos clínicos e experimentais. Jornal Vascular Brasileiro, v. 16, n. 2, p. 88-91, 2017.

MOURA, M. S. B.; GALVINCIO, J. D.; BRITO, L. T. L.; SOUZA, L. S. B.; SÁ, I. I. S.; SILVA, T. G. F. Clima e água de chuva no Semiárido. In: BRITO, L. T. L.; MOURA, M. S. B.; GAMA, G. F. B. (ed.). Potencialidades da água de chuva no Semiárido brasileiro. Petrolina: Embrapa Semiárido, 2007.

NOGUEIRA FILHO, G. C.; RONCATTO, G.; RUGGIERO, C.; OLIVEIRA, J. C.; MALHEIROS, E. B. Florescimento e produção de maracujazeiro-amarelo obtido por enxertia hipocotiledonar em Jaboticabal - SP e Araguari - MG. Revista Brasileira de Fruticultura, v. 33, n. 1, p. 227-236, 2011.

OLIVEIRA, J. C.; RUGGIERO, C. Espécies de maracujá com potencial agronômico. In: FALEIRO, F. G.; JUNQUEIRA, N. T. V.; BRAGA, M. F. Maracujá: germoplasma e melhoramento genético. Planaltina, DF: Embrapa Cerrados, 2005. p. 143-158.

QUEIROGA, R. C. F.; PUIATTI, M.; FONTES, P. C. R.; CECON, P. R. Produtividade e qualidade de frutos de meloeiro variando número de frutos e de folhas por planta. Horticultura Brasileira, v. 26, n. 2, p. 209-215, 2008.
R CORE TEAM. $R$ : a language and environment for statistical computing. Vienna: R Foundation for Statistical Computing, 2018.

RIGDEN, P. The passion fruit growing guide. Queensland: Department of Employment, Economic Development and Innovation, 2011.

SCORZA, L. C. T.; HERNANDES-LOPES, J.; MELO-DE-PINNA, G. F. A.; DORNELAS, M. C. Expression patterns of Passiflora edulis APETALA1/ FRUITFULL homologues shed light onto tendril and corona identities. EvoDevo, v. 8, n. 3, p. 2-15, 2017.

SILVA, H. A.; CORRÊA, L. S.; BOLIANI, A. C. Efeitos do sistema de condução, poda e irrigação na produção do maracujazeiro doce. Revista Brasileira de Fruticultura, v. 26, n. 3, p. 450-453, 2004.

TUPINAMBÁ, D. D.; COSTA, A. M.; COHEN, K. O.; PAES, N. S.; FALEIRO, F. G.; CAMPOS, A. V. S.; SANTOS, A. L. B.; SILVA, K. N.; JUNQUEIRA, N. T. V. Pulp yield and mineral content of commercial hybrids of yellow passion fruits. Brazilian Journal of Food Technology, v. 15, n. 1, p. 15-20, 2012.

VIANA, A. P.; GONÇAlveS, G. M. Genética quantitativa aplicada ao melhoramento genético do maracujazeiro. In: FALEIRO, F. G.; JUNQUEIRA, N. T. V.; BRAGA, M. F. Maracujá: germoplasma e melhoramento genético. Planaltina, DF: Embrapa Cerrados, 2005. p. 243-275. 